\title{
Evolution of Arkona Basin environment in the Holocene in the light of diatom research
}

\author{
Beata Janczak-Kostecka \\ Department of Quaternary Geology and Paleogeography, Adam Mickiewicz University in Poznań, Poland; kostecka@amu.edu.pl
}

\begin{abstract}
This article presents the results of diatom studies from three cores taken from the Arkona Basin. The main stages of the Baltic Sea evolution in the Holocene - Ancylus Lake, Mastogloia Sea, Littorina Sea, and Post-Littorina Sea - were identified in diatom assemblages. The transition stage between Ancylus Lake and Littorina Sea, called Mastogloia Sea, was not such a long period as in the Mecklenburg Bay but was essential in the evolution of the Baltic Sea. The most pronounced feature of this period was an increase in the number of halophilous species, which reflected the existence of the littoral environment at the onset of this stage. The appearance and development of halophilous species was stimulated by stepwise inflows of saline waters. The composition of diatom assemblages reflected natural eutrophication of the Baltic Sea during the Littorina Sea stage.
\end{abstract}

Key words: diatoms, Mastogloia Sea, Ancylus Lake, Littorina Sea, southwestern Baltic Sea, Arkona Basin

\section{Introduction}

The environment of the Baltic Sea during the last 10000 years was affected by considerable salinity changes and fluctuation of sea level. The basin was transformed from a lacustrine to a marine reservoir twice during the Yoldia Sea stage and the Littorina Sea stage. These fluctuations completely changed the existing ecosystems, which had to adapt to new environmental conditions. Since the 1990s, complex interdisciplinary studies concerning the reconstruction of the sea level and salinity of the Baltic Sea in the Holocene have been carried out in the Arkona Basin area (Jensen et al. 1997, Lemke et al. 2001, Witkowski et al. 2005). These studies determined the maximal extent of the Baltic Ice Lake, which flooded the Arkona Basin during its high level at $10300 \mathrm{cal} \mathrm{BP}$. The sediments of the Baltic Ice Lake were covered by deposits of the Ancylus Lake, which appeared in the Arkona Basin at $9200 \mathrm{cal}$ BP (Berglund et al. 2005, Björck 1995, Jensen et al. 1999).

The evolution of a transition stage between the Ancylus Lake and the Littorina Sea, called the Mastogloia Sea (Witkowski et al. 2005), and the Littorina transgression rate have not yet been recognized in detail in the Arkona Basin area. Knowledge of the sea level and salinity fluctuations in the Holocene are essential for reconstruction of the Mastogloia Sea and Littorina Sea stages. Diatoms are sensitive to changes of environmental parameters such as salinity, depth, trophy, and alkalinity. Studies of diatom flora assemblages are a suitable method for palaeoenvironmental reconstruction of the evolution of the water reservoirs. Although there are numerous publications from the Baltic Sea area, there are many questions about the causes of different scenarios of environmental evolution during the Littorina transgression in the southwestern Baltic basin. The next important problem for the studied area is the legitimacy of division of the marine stages: the Mastogloia, Littorina, and Post-Littorina stages.

\section{Materials and methods}

The sediment samples were obtained from cores taken from the central and southern parts of the Arkona Basin at depths below $40 \mathrm{~m}$ b.s.l.. The cores were taken by gravity corer along seismo-acoustic profiles during cruises of the research vessels FS A. v. Humboldt, FS Maria S. Merian, and FS Elisabeth Mann Borgese by the Leibniz Institute for Baltic Sea Research, Warnemünde in the period 20012013. The cores were cut into $1-\mathrm{cm}$ sediment samples.

The sediment age in core 233220 was determined by means of ${ }^{14} \mathrm{C}$ dating in the Poznan Radiocarbon Laboratory.

The diatom samples were prepared according to standard methods (Battarbee 1986). The counting method 


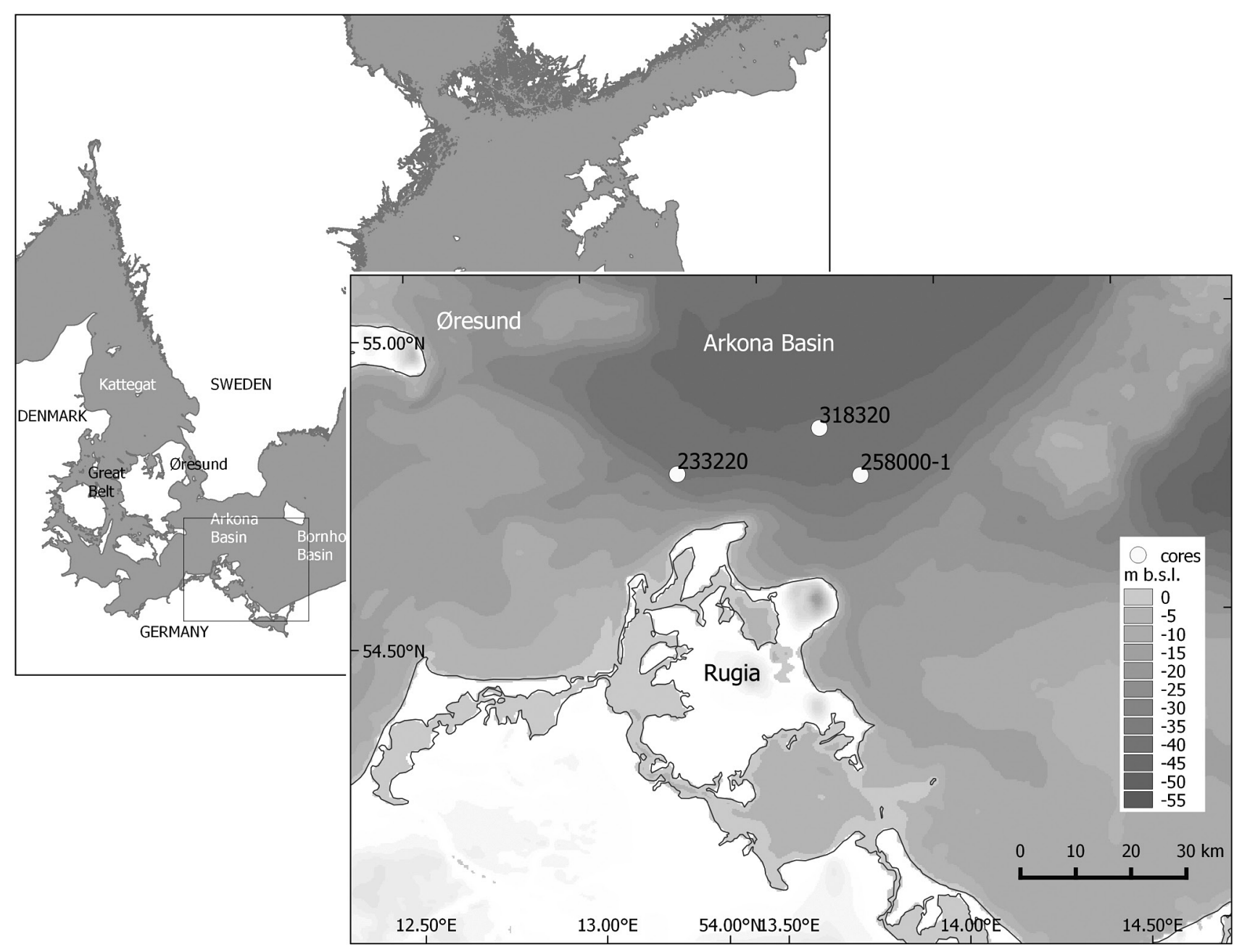

Fig. 1. Location map of studied cores

of Schrader and Gersonde (1978) was used, and between 300 and 500 valves were counted in each sample in order to estimate the percentage abundance of particular taxa. The diatoms were divided into groups according to their biotope requirements; planktonic and benthic groups were distinguished (Round 1981). Diatoms were grouped with respect to their salinity requirements according to Kolbe's (1927) halobous system: euhalobous (salinity > 30 PSU), mesohalobous (5-20 PSU), oligohalobous halophilous ( $<5$ PSU), indifferent (0-2 PSU), and halophobous (0 PSU). The percentage content of habitat and halobous groups was counted in the core.

The identification and ecological information was obtained from the studies by Bąk et al. (2012), Denys (1991), Krammer and Lange-Bertalot (1988, 1986, 1991a, b), Lange-Bertalot and Genkal (1999), Krammer (2002), Pliński and Witkowski (2009, 2011), Reichardt (1999), Snoeijs (1993), Snoeijs and Vilbaste (1994), Snoeijs and Popova (1995), Snoeijs and Kasperoviciene (1996), Snoeijs and Balashova (1998), Witkowski (1994), and Witkowski et al. (2000).

The percentage content of all ecological groups was estimated in each sample. Diatom assemblage zones (DAZs) were distinguished based on differences in the species compositions, the relative frequencies of diatom taxa, and the prevalent ecological and habitat groups, and also according to the algorithm CONISS (Grimm 1987) implemented in the statistical R package Rioja (Juggins 2013) and tested by the "broken-stick model" (Bennett 1996).

\section{Results}

The diatom flora was abundant and well preserved in the analysed sediment material. The diatom valves were rare and poorly preserved only in clay sediment. The analysed cores were divided into three diatom zones according to the distribution of ecological groups (DAZ A, DAZ B, and DAZ C).

\section{Core 258000-1}

Core 258000-1 was taken from the southeastern part of Arkona Basin and was built of clay, silty clay, humus clay, and mud (Fig. 2). The diatom flora was rare and poorly preserved in bottom clay sediments. From the depth of 470 $\mathrm{cm}$ to the top of the core, the diatoms were abundant and the state of preservation enabled identification. The lowermost zone, DAZ A with subzones DAZ A1 and DAZ A2, 


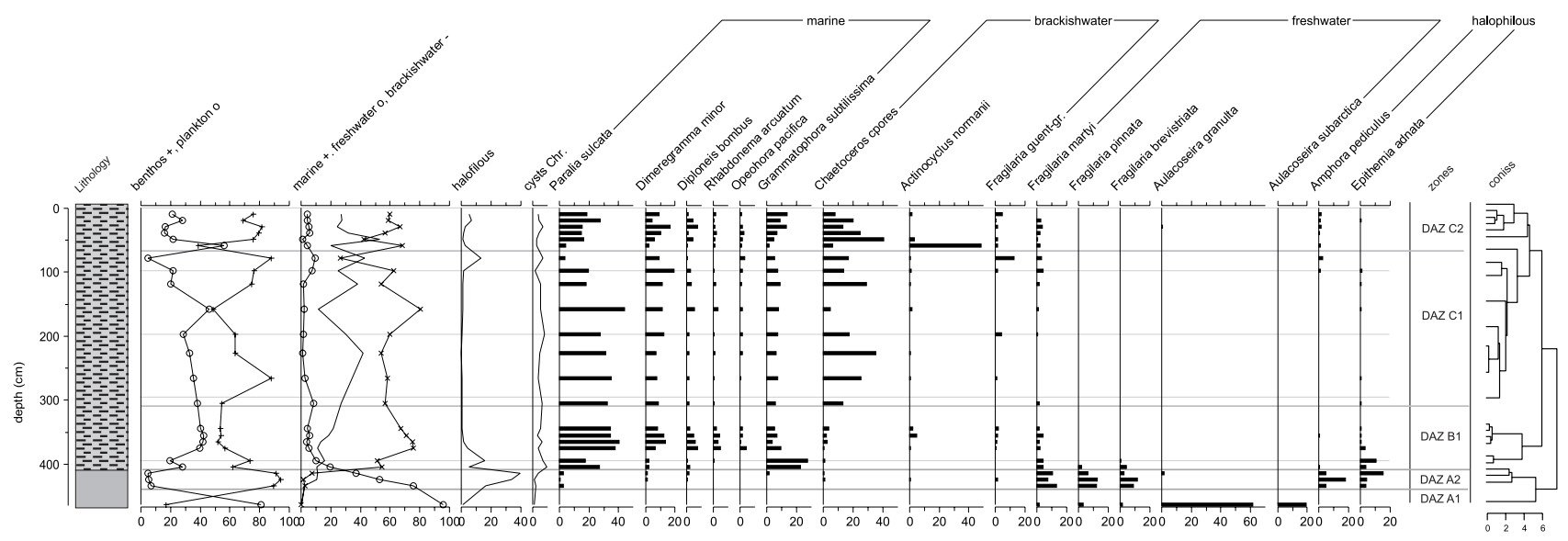

mud

humus clay

Fig. 2. Ecological groups and dominant diatom species in core 258000-1

was identified in silty clay sediments. The contribution of each halobous and ecological group changed with core depth. The content of benthos species increased upward in the zone from 20 to $97 \%$, while the number of plankton species decreased from 80 to $3 \%$. The freshwater forms were the most abundant among the halobous group but the contribution decreased upward from 99 to $25 \%$. The freshwater species were represented by Aulacoseira granulata, A. islandica, Fragilaria martyi, F. pinnata and F. brevistriata and were accompanied by the halophilous species $\mathrm{Am}$ phora pediculus and Epithemia adnata. The marine taxa Paralia sulcata, Dimeregramma minor, Diploneis bombus and Grammatophora subtilissima appeared in the top part of zone DAZ A2 and represented up to $2 \%$ of species.

The subzone DAZ B1 encompassed the sediment interval of $310-410 \mathrm{~cm}$. This subzone was characterized by an upward decrease of freshwater and halophilous taxa to a few percent and increases of marine taxa to $76 \%$ and brackish water taxa to $25 \%$. The marine species of this subzone comprise P. sulcata, D. minor, D. bombus, G. subtilissima and Rhabdonema arcuatum, while brackish-water forms comprise Chaetoceros, Actinocyclus normanii and Opephora guenter-grasii. The benthic taxa accounted for $60 \%$ of species while planktonic taxa accounted for $40 \%$. Chrysophyceae cysts were also observed in subzone DAZ B1.

The next subzone, DAZ C1, was distinguished in the sediment interval of $70-310 \mathrm{~cm}$. The most abundant group constituted benthic species, with contents ranging from 65 to $88 \%$. Only at a depth of $160 \mathrm{~cm}$ did the contribution of benthos decrease to $48 \%$. Amongst the halobous group, the marine species (60-80\%) were the most abundant and were represented by $P$. sulcata, D. minor, and G. subtilissima. They were accompanied by brackish-water forms (around 40\%), Chaetoceros spores, A. normanii and $O$. guenter-grasii. The freshwater forms were not observed, while the content of halophilous forms was $1 \%$. Only in the top part of the core did the number of halophilous taxa increase to $2 \%$.

The most abundant diatom group in the uppermost subzone, DAZ C2, was benthic taxa (around 80\%). Only at a depth of $60 \mathrm{~cm}$ did the content of benthos decrease to $40 \%$, while the content of plankton was $60 \%$. The marine species $(60 \%)$ were represented by $P$. sulcata, D. minor and $G$. subtilissima, while brackish-water forms were represented by Chaetoceros spores, $A$. normanii and $O$. guenter-grasii. Freshwater (F. martyi) and halophilous ( $A$. pediculus and E. adnata) taxa were also observed.

\section{Core 318320}

Core 318320 was taken from the central part of the Arkona Basin (Fig. 1), $11 \mathrm{~km}$ to the northwest of core 2580001 at a depth of $45 \mathrm{~m}$ b.s.l. The core was built of silty clay and mud. The diatom valves in the bottom part of the core (below $510 \mathrm{~cm}$ ) were rare and poorly preserved, although some valves were suitable for identification. In the mud sediments, diatom flora was abundant and well preserved. Similarly to core $258000-1$, three diatom zones with subzones were distinguished.

The lowermost subzone, DAZ A1, was distinguished in silty clay sediments at a depth interval of 490-570 cm (Fig. 3). Diatoms were observed in small number and single valves were noted. Amongst them were $F$. pinnata, $F$. martyi, F. lapponica, Cocconeis disculus and Navicula scuteloides, which reflected the freshwater environment.

The diatom subzone A1 encompassed the sediment interval of 460-490 cm. The diatom flora was diverse in respect of species content and well preserved. The benthos forms were represented mainly by marine species (Fig. 3). The most dominant taxa was planktonic $P$. sulcata (30-40\% of all identified species). Furthermore, $D$. minor, R. arcuatum, Diploneis smithii, D. bombus and $G$. subtilissima were also abundant. They were accompanied by a few freshwater taxa, F. martyi and F. lapponica. The Chrysophyceae cysts were observed in considerable amounts, representing $17 \%$ of species in the bottom part of the subzone.

The subzone DAZ B1 was distinguished in the sediment interval from 360 to $460 \mathrm{~cm}$. The most dominant species were marine diatoms, which made a contribution of $66 \%$, although the content of brackish-water species 


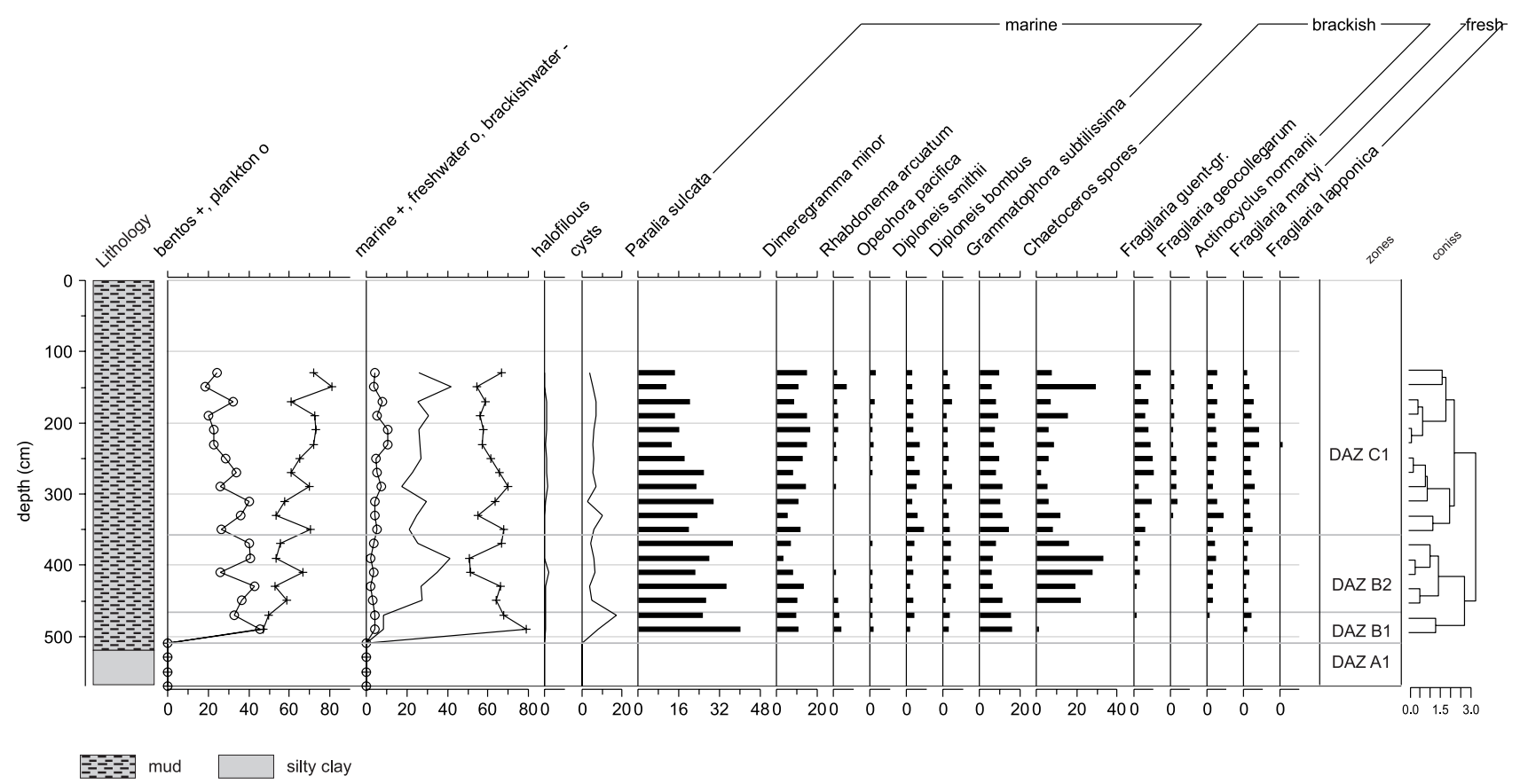

Fig. 3. Ecological groups and dominant diatom species in core 318320

showed a considerable increase upwards from 8 to $40 \%$. The brackish-water species were represented by Chaetoceros spores, A. normanii and $O$. guenter-grasii. A few valves of the halophilous diatoms Cyclotella meneghinia$n a$ and $A$. pediculus (below $1 \%$ ) were also observed.

The uppermost diatom subzone, $\mathrm{C} 1$, encompasses the sediment interval of 120-360 cm. Amongst the diatom assemblages, the benthos forms were dominant (80\%). Amongst the halobous groups the most abundant were marine species (56\%) including P. sulcata, D. minor, R. arcuatum, D. smithii, G. subtilissima and Opephora pacifica and brackish-water species (30\%) including Chaetoceros, A. normanii and O. guenter-grasii. The characteristic feature of this part of the core was a decrease in the percentage contribution of $P$. sulcata from 30 to $14 \%$ and an increase of $D$. minor to $18 \%$. The freshwater forms $(5-10 \%)$ and halophilous species $(2 \%)$ occurred only in small amounts. The freshwater group was represented by F. martyi and F. lapponica and the halophilous group by A. pediculus.

\section{Core 233220}

The core 233220 comes from the southwestern part of the Arkona Basin (Fig. 1) from a water depth of $40.4 \mathrm{~m}$ b.s.l. located $27 \mathrm{~km}$ to the southwest of core 318320 . The core was built from clay at the bottom, humus clay, and mud at the top. The sediment sample of humus clay taken at a depth of $450 \mathrm{~cm}$ was dated at $8910 \pm 50 \mathrm{BP}$ and calibrated at 9481-9793 cal BP, according to the Intcal09 table (Reimer et al. 2009). The sample of mud from the depth of $430 \mathrm{~cm}$ was dated at $8170 \pm 50 \mathrm{BP}$ and was calibrated at 8537-8770 cal BP according to the use of Marine09 data sets (Reimer et al. 2009) with a reservoir age of 375 years based on the Chrono Marine Reservoir Database
(Lougheed et al. 2013). The core was divided into three diatom zones, similarly to the previously presented cores. Diatom assemblages were abundant in respect of the number of species and the amount of valves only in mud sediments. In the bottom part of the core in clay and humus clay sediments, diatoms were rare and poorly preserved.

The subzone DAZ A1 was distinguished in bottom clay and humus clay sediments in the depth interval of $420-520 \mathrm{~cm}$ (Fig. 4). In this subzone, very rare diatom valves occurred. Single freshwater diatom valves of $F$. pinnata, F. martyi, F. lapponica, C. disculus and halophilous C. pseudothumensis, C. meneghiniana, C. atomus, Achnanthes clevei var. bottnica and A. pediculus were observed.

Diatom subzone B1 encompasses the sediment interval of $380-420 \mathrm{~cm}$. The diatom flora of this subzone was rich in species, with a high number of valves which were very well preserved. The most dominant were benthonic species $(80 \%)$. Euhalobous forms were the most abundant among the ecological groups and attained $72 \%$ in the top part of the subzone. Species included in this group comprised $P$. sulcata, D. minor, D. smithii and G. subtilissima. They were accompanied by brackish forms (20\%) of $F$. guenter-grassii and Opephora burchardtiae and halophilous forms $(20 \%)$ of C. meneghiniana and E. adnata. The freshwater species did not attain $12 \%$ and were represented mainly by Amphora inariensis (5\%). The Chrysophyceae cysts $(10 \%)$ were observed in significant number.

The overlaid diatom zone B2 encompasses the sediment interval of $320-380 \mathrm{~cm}$. Diatom flora were characterized by upwards decreases of freshwater and halophilous forms to a few percent and increases of marine forms to $79 \%$ and brackish forms to $24 \%$. Marine species were represented by P. sulcata, D. minor, D. smithii, G. subtilissima and Actinocyclus octonarius, while brackish-water diatoms were 


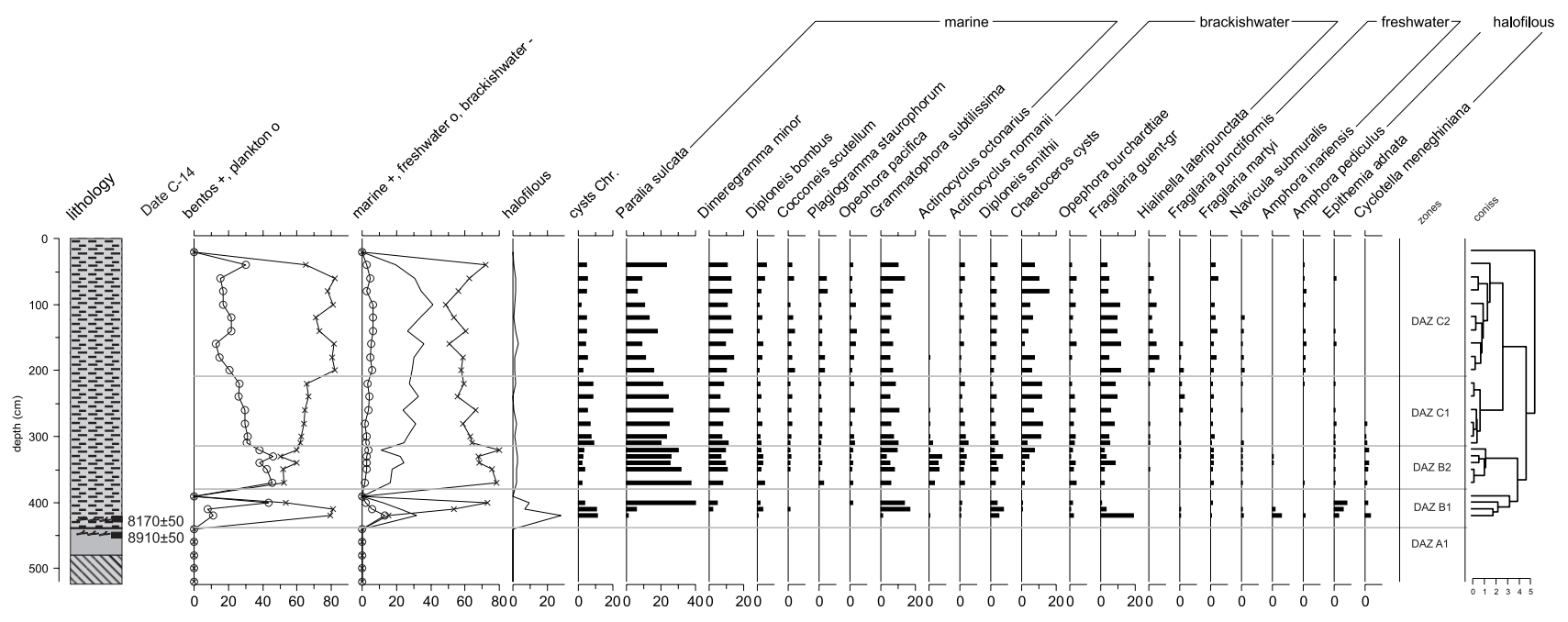

humus clay $\quad$ MIII sity clay $\square$ fine sand

Fig. 4. Ecological groups and dominant diatom species in core 233220

represented by Chaetoceros spores, $A$. normanii and $O$. guenter-grasii. This part of the core consisted of $38-45 \%$ planktonic forms and $55-62 \%$ benthonic forms.

Diatom subzone $\mathrm{C} 1$ was distinguished at a depth of $110-320 \mathrm{~cm}$ and was characterized by an upward increase of the predominance of benthonic forms (67\%) over planktonic ones (33\%). P. sulcata, D. minor and G. subtilissima were the most dominant marine species, while Chaetoceros spores, O. burchardtiae and $O$. guenter-grasii were observed among the brackish-water species. The contribution of freshwater species did not exceed 5\% and that of halophilous ones did not exceed $2 \%$. A contribution of Chrysophyceae cysts (9\%) was also noted.

The uppermost subzone DAZ C2 encompassed the sediment interval between 20 and $110 \mathrm{~cm}$. Similarly to subzone DAZ C1, there was an increase in the predominance of benthonic forms (82\%) over planktonic ones $(18 \%)$. The contribution of marine species increased to $71 \%$ while the contribution of brackish forms decreased to $20 \%$. P. sulcata, D. minor, and G. subtilissima were the most frequent marine taxa and Chaetoceros spores, O. guenter-grasii and Hyalinella lateripunctata were the most frequent brackish taxa. Similarly to core 318320 , the characteristic feature of this subzone was a decrease in the content of $P$. sulcata from 24 to $6 \%$ and an increase in the content of $D$. minor to $15 \%$. Freshwater species $(6 \%)$ were represented by $F$. martyi and $F$. punctiformis. The contribution of halophilous forms was less than $2 \%$ and was represented by $A$. pediculus.

\section{Discussion}

The results of the diatom analysis of the presented sediment cores allow discussion of the evolution of the Arkona Basin during the Holocene. The stages of evolution of the Baltic Sea in the Holocene - the Ancylus Lake, Mastogloia Sea, Littorina Sea, and Post-Littorina Sea stages - were identified in the sediments of the analysed cores.

\section{Ancylus Lake stage}

The sediments of subzones DAZ A1 and DAZ A2 from core 258000-1, subzone DAZ A1 from core 318320, and DAZ A1 from core 233220 were deposited during the maximum extent of Ancylus Lake (Jensen et al. 1999). The age of sediments was confirmed by the date of 94819793 cal BP from subzone A1 in core 233220. Diatom flora of this stage was rare and poorly preserved in all analysed samples. Freshwater and fresh-brackish-water species from the genus Fragilaria - F. pinnata, F. martyi, $F$. lapponica and F. brevistriata - as well as Cocconeis disculus and Amphora inariensis were noted. Such diatom assemblages recorded a shallow freshwater reservoir due to the dominant benthonic form. The planktonic freshwater species Aulacoseira granulata and A. subarctica were observed in the bottom part of the Ancylus sediments, which reflects a higher water level.

\section{Mastogloia Sea stage}

The Mastogloia Sea was distinguished as the stage of the first marine inflows to the Baltic basin dated at 8400 and 8300 cal BP in Mecklenburg Bay (Witkowski et al. 2005). Diatoms of this stage reflected a transition environment between the freshwater flora of Ancylus Lake and the marine flora of the Littorina Sea. The Mastogloia stage was represented by subzones DAZ B1 from all analysed cores. The characteristic feature of the diatom assemblages was the occurrence of the halophilous species Epithemia adnata, Cyclotella meneghiniana and Amphora pediculus. Halophilous species prefer freshwater environments but an admixture of salt stimulates their development and then they may become abundant (Krammer, Lange-Bertalot 1991a, b). They were accompanied by the freshwater forms Amphora inariensis, Fragilaria martyi, $F$. pinnata, F. brevistriata, marine forms of Paralia sulcata, Grammatophora subtilissima, Dimeregramma minor and the brackish-water forms of Chaetoceros spores and 
O. guenter-grasii. The contribution of planktonic forms in the beginning phase was slight $(5-10 \%)$, whereas the benthonic species were dominant (90-95\%). The diatom composition described above reflects the existence of a littoral environment at the onset of this stage. Previous studies confirmed the existence of the Mastogloia Sea stage in the Mecklenburg Bay sediments (Witkowski et al. 2005), where a transition stage with a dominance of halophilous and brackish species was clearly recognized. Previous studies of sediments from the deepest part of Arkona Basin reported the lack of a transition stage (Rößler et al. 2011). The presented studies suggested the existence of a short transition period.

\section{Littorina Sea stage}

The development of transgression and increasing salinity were recorded by the increasing content of marine species (P. sulcata, G. subtilissima, D. minor, D. smithii, D. bombus, A. octonarius) and brackish-water species (Chaetoceros spores, O. burchardtiae, O. guenter-grasii, $F$. geocollegarum). The freshwater and halophilous forms showed the opposite trend. The benthic forms still predominated over planktonic ones. The sediments of the Littorina Sea were represented by diatom subzones DAZ B2 and DAZ C1 from cores 258000-1 and 233220, where stabilization of the marine conditions was recorded. Significantly increasing salinity was confirmed by changes in diatom composition and was also noted in other cores from the Arkona Basin and Pomeranian Bay (Kostecki, Janczak-Kostecka 2011, 2012).

The natural eutrophication of the Baltic Sea was also a result of oceanic water inflows. The trophic condition changed from mesotrophic to eutrophic in this stage. It was recorded by diatom flora and confirmed by the occurrence of indicator species for the fertile waters of the marine littoral (e.g. Chaetoceros spp., Actinocyclus normanii oraz Cyclotella spp.)

\section{Post-Littorina Sea stage}

The sediment of the top part of the analysed cores was deposited in the Post-Littorina Sea stage. This stage was represented by the diatom subzones DAZ $\mathrm{C} 1$ from core 318320 and DAZ C2 from cores 258000-1 and 233220. The subzones were characterized by an upward decrease in marine species and increase in brackish-water and freshwater diatoms. This could be explained by a stepwise drop in salinity during the Post-Littorina Sea stage. Similar conditions were also observed in Gdańsk Basin (Emelyanov, Vaikutienè 2013) and Bornholm Basin (Andrén et al. 2000). The diatom assemblage was represented by marine species (P. sulcata, G. subtilissima, D. minor) and brackish-water species (Chaetoceros spores, $O$. guenter-grasii and $H$. lateripunctata). The characteristic feature of this subzone was a decrease in the content of $P$. sulcata from 30 to $14 \%$ and increase of D. minor to $18 \%$. This phenomenon probably reflected fluctuation in the
Baltic Sea level and changes in the composition of habitat groups. The freshwater and halophilous species existed in this subzone in small numbers.

\section{Conclusion}

The presented diatom studies demonstrate the existence of a transition stage between the Ancylus Lake and the Littorina Sea. It was not such a long period as in Mecklenburg Bay but it was essential in the evolution of the Baltic Sea. The characteristic feature of this period was an increase in halophilous species, whose appearance and development was stimulated by a stepwise inflow of saline waters. The inflow of saline waters led to natural eutrophication of the Baltic Sea and contributed to the development of marine diatoms, with dominance of P. sulcata, the species characteristic of the Littorina Sea stage.

\section{Acknowledgements}

I wish to thank Professor Andrzej Witkowski from Szczecin University and Matthias Moros from the Leibniz Institute for Baltic Sea Research in Warnemünde for their help in obtaining material and Małgorzata Schade for sample preparation. The study was financed by the Polish National Science Centre within the framework of project 2011/01/B/ST10/06497.

\section{References}

Andrén E., Andrén T., Sohlenius G., 2000. The Holocene history of the southwestern Baltic Sea as reflected in a sediment core from the Bornholm Basin. Boreas 29: 233-250, DOI: http://dx.doi. org/10.1080/030094800424259.

Battarbee R.W., 1986. Diatom analysis. In: Berglund, B.E. (ed), Handbook of Holocene paleoecology and paleohydrology. John Wiley and Sons, London: 527-570.

Bąk M., Witkowski A., Żelazna-Wieczorek J., Wojtal A., Szczepocka E., Szulc K., Szulc B., 2012. Klucz do oznaczania okrzemek w fitobentosie na potrzeby oceny stanu ekologicznego wód powierzchniowych w Polsce. Biblioteka Monitoringu Środowiska, Warszawa.

Bennett K.D., 1996. Determination of the number of zones in a biostratigraphical sequence. New Phytology 132: 155-170.

Berglund B.E., Sandgren P., Barnekow L., Hannon G., Jiang H., Skog G., Yu S., 2005. Early Holocene history of the Baltic Sea, as reflected in coastal sediments in Blekinge, southeastern Sweden. Quaternary International 130: 111-139, DOI: http://dx.doi.org/10.1016/j. quaint.2004.04.036.

Björck S., 1995. A review of the history of the Baltic Sea, 13.0-8.0 ka BP. Quaternary International 27: 19-40, DOI: http://dx.doi. org/10.1016/1040-6182(94)00057-C

Denys L., 1991. A check-list of the diatoms in the Holocene deposits of the western Belgian coastal plan with a survey of their apparent ecological requirements. I. Introduction, ecological code and complete list. Professional Paper Belgische Geologisch Dienst 246: 1-41.

Emelyanov E.M., Vaikutienė G., 2013. Holocene environmental changes during transition Ancylus-Litorina stages in the Gdansk Basin, south-eastern Baltic Sea. Baltica 26: 71-82, DOI: http://dx.doi. org/10.5200/baltica.2013.26.08.

Grimm E.C., 1987. CONISS: a FORTRAN 77 program for stratigraphically constrained cluster analysis by the method of incremental sum of squares. Comput. Geosci. 13: 13-35. 
Jensen J.B., Bennike O., Witkowski A., Lemke W., Kuijpers A., 1997. The Baltic Ice Lake in the southwestern Baltic: sequence-, chronoand biostratigraphy. Boreas 26: 217-236, DOI: http://dx.doi. org/10.1111/j.1502-3885.1997.tb00853.x.

Jensen J.B., Bennike O., Witkowski A., Lemke W., Kuijpers A., 1999. Early Holocene history of the southwestern Baltic Sea: the Ancylus Lake stage. Boreas 28: 437-453, DOI: http://dx.doi. org/10.1111/j.1502-3885.1999.tb00233.x.

Juggins S., 2013. Rioja: analysis of Quaternary science data.

Kolbe R.W., 1927. Zur Ökologie, Morphologie, und Systematik der Brackwasser-Diatomeen. Pflanzenforschung 7: 1-146.

Kostecki R., Janczak-Kostecka B., 2011. Holocene evolution of the Pomeranian Bay environment, southern Baltic Sea. Oceanologia 53: 471-487, DOI:10.5697/oc.53-1-TI.471.

Kostecki R., Janczak-Kostecka B., 2012. Holocene environmental changes in the south-western Baltic Sea reflected by the geochemical data and diatoms of the sediment cores. Journal of Marine Systems 105-108: 106-114, DOI: http://dx.doi.org/10.1016/j. jmarsys.2012.06.005.

Krammer K., 2002. Cymbella. In: Lange-Bertalot, H. (ed), Diatoms of Europe 3. A.R.G. Gantner Verlag K.G., Ruggell.

Krammer K., Lange-Bertalot H., 1986. Bacillariophyceae 1, Naviculaceae. In: Ettl H., Gerloff J., Heynig H., Mollenhauer D. (eds), Süsswasserflora von Mitteleuropa 2, 1. Fisher, Stuttgart.

Krammer K., Lange-Bertalot H., 1988. Bacillariophyceae 2, Epithemiaceae, Bacillariacea, Surirellaceae. In: Ettl H., Gerloff J., Heynig H., Mollenhauer D. (eds), Süsswasserflora von Mitteleuropa 2, 2. Fisher, Stuttgart.

Krammer K., Lange-Bertalot H., 1991a. Bacillariophyceae 3, Centrales, Fragilariaceae, Eunotiaceae. In: Ettl H., Gerloff J., Heynig H., Mollenhauer D. (eds), Süsswasserflora von Mitteleuropa 2, 3. Fischer, Stuttgart, p. 577.

Krammer K., Lange-Bertalot H., 1991b. Bacillariophyceae 4, Achnanthacea. In: Ettl H., Gerloff J., Heynig H., Mollenhauer D. (eds), Süsswasserflora von Mitteleuropa 2, 4. Fischer, Stuttgart, p. 437.

Lange-Bertalot H., Genkal S.I., 1999. Diatomeen aus Sibirien I. Iconographia Diatomologica 6, 1-296.

Lemke W., Jensen J.B., Bennike O., Endler R., Witkowski A., Kuijpers A., 2001. Hydrographic thresholds in the western Baltic Sea: Late Quaternary geology and the Dana River concept. Marine Geology 176: 191-201, DOI: http://dx.doi.org/10.1016/S0025-3227(01)00152-9

Lougheed B.C., Filipsson H.L., Snowball I., 2013. Large spatial variations in coastal $14 \mathrm{C}$ reservoir age - a case study from the Baltic Sea. Clim. Past 9: 1015-1028, DOI: http://dx.doi.org/10.5194/cp-91015-2013.

Pliński M., Witkowski A., 2009. Okrzemki - Bacillariophyta (Diatoms). Część pierwsza: Okrzemki centryczne (Coscinodiscophyceae). In:
Pliński M. (ed), Flora Zatoki Gdańskiej I Wód Przyległych (Bałtyk Południowy). 4/1. Wydawnictwo Uniwersytetu Gdańskiego, Gdańsk. Pliński M., Witkowski A., 2011. Okrzemki - Bacillariophyta (Diatoms). Część druga: Okrzemki pierzaste (Fragilariophyceae, Eunotophycidae, Achnanthales). In: Pliński M. (ed), Flora Zatoki Gdańskiej I Wód Przyległych (Bałtyk Południowy). 4/2. Wydawnictwo Uniwersytetu Gdańskiego, Gdańsk.

Reichardt R., 1999. Zur Revision der Gattung Gomphonema. Iconographia Diatomologica 8: 1-206.

Reimer P.J., Baillie M.G.L., Bard E., Bayliss A., Beck J.W., Blackwell P.G., Bronk Ramsey C., Buck C.E., Burr G.S., Edwards R.L., Friedrich M., Grootes P.M., Guilderson T.P., Hajdas I., Heaton T.J., Hogg A.G., Hughen K.A., Kaiser K.F., Kromer B., McCormac F.G., Manning S.W., Reimer R.W., Richards D.A., Southon J.R., Talamo S., Turney C.S.M., Van Der Plicht J., Weyhenmeyer C.E., 2009. IntCa109 and Marine09 radiocarbon age calibration curves, $0-50,000$ years cal BP. Radiocarbon 51: 1111-1150.

Rößler D., Moros M., Lemke W., 2011. The Littorina transgression in the southwestern Baltic Sea: new insights based on proxy methods and radiocarbon dating of sediment cores. Boreas 40: 231-241, DOI: http://dx.doi.org/10.1111/j.1502-3885.2010.00180.x.

Round F.E., 1981. The biology of algae. Cambridge University Press. Cambridge, London, New York, New Rochelle, Melbourne, Sydney.

Schrader H., Gersonde R., 1978. Diatoms and silicoflagellates in the eight meters sections of the lower Pleistocene at Capo Rossello. Utrecht Micropaleontological Bulletins 17: 129-176.

Snoeijs P., 1993. Intercalibration and distribution of diatom species in the Baltic Sea, 1. Opulus Press Uppsala.

Snoeijs P., Balashova N., 1998. Intercalibration and distribution of diatom species in the Baltic Sea, 5. Opulus Press Uppsala.

Snoeijs P., Kasperoviciene J., 1996. Intercalibration and distribution of diatom species in the Baltic Sea, 4. Opulus Press Uppsala.

Snoeijs P., Popova M., 1995. Intercalibration and distribution of diatom species in the Baltic Sea, 3. Opulus Press Uppsala.

Snoeijs P., Vilbaste S., 1994. Intercalibration and distribution of diatom species in the Baltic Sea, 2. Opulus Press Uppsala.

Witkowski A., 1994. Recent and fossil diatom flora of the Gulf of Gdańsk the Southern Baltic Sea. Bibliotheca Diatomologica 28: 1-313.

Witkowski A., Broszinski A., Bennike O., Janczak-Kostecka B., Bo Jensen J., Lemke W., Endler, R., Kuijpers A., 2005. Darss Sill as a biological border in the fossil record of the Baltic Sea: evidence from diatoms. Quaternary International 130: 97-109, DOI: http://dx.doi. org/10.1016/j.quaint.2004.04.035.

Witkowski A., Lange-Bertalot H., Metzeltin D., 2000. Diatom Flora of Marine Coasts. I. Iconographia Diatomologica 7: 1-925. 